\title{
Shaping Entrepreneurship's Human Resource by Green Entrepreneurial Behaviour Approachment: Instrument Preparation's Preliminary Study
}

\author{
Hastin Umi Anisah \\ Wimby Wandary
}

Economic and Business Faculty - Lambung Mangkurat University hastin_umi@yahoo.com; wimbywan234@gmail.com

\section{Doi:10.5901/mjss.2015.v6n5s5p109}

\begin{abstract}
This research aims to find the real phenomenon about student's green entrepreneurial behavior principles comprehension student who choose the specific field of study Strategic Management and Entrepreneurship. Intent to form green entrepreneurs, the series of research first stated by identifies whether the expectation from the finely inserting of the green entrepreneurial behavior principles into the lecturing activities in subject course of green entrepreneurial behavior, is meet the expectation of being internalized. Utilization of descriptive statistic is applied to describe individual respondent's characteristics. The application descriptive statistics of frequency to seek for answer research's question about the amount of the students (in percentage) who choose the specific field of study: Strategic Management and Entrepreneurship comprehends the green entrepreneurial behavior principles. There is only $10 \%$ of the student perceived themselves understand the green entrepreneurial behavior principles. It is suggested to provide the subject of green entrepreneurial behavior inclusively in lecturing material formally/ explicitly, or deliver it as specific part/ chapter of learning material. It is necessary to prepare the faculty with relevant competence to deliver the course of material: green entrepreneurial behavior, besides updating the content of the curriculum more than just the system of administration only
\end{abstract}

Keywords: green entrepreneurial behavior, green entrepreneurship, higher education.

\section{Introduction}

There is a significant urgency to increase the quality and amount of entrepreneurs in Indonesia. The urgency lies on reality that the available labor market has not yet able to absorb the available workforce to stimulate the national economy. Classified as the developed country, Indonesia requires some more entrepreneurs, at least to meet the least $2 \%$ of its population. According to Syarief, cited by ed by Hadi and Jihad (2012), Indonesia's entrepreneurs is only 1.56\% of the population meanwhile it requires about $2 \%$ or more of the population to be industrialized country. The Ministry of Economy, as cited in Ayu (2013), cultivates students and scholars to become entrepreneurs to provide leverage for advanced and independent Indonesia. The government's willpower interpreted by the Ministry of Education and Culture through the higher education's curriculum by adjusting lecturing compulsory subject of Entrepreneurship. By the existence of the higher education's compulsory subject, each faculty in Indonesia organizes it in lecturing activities, that sometime considered under conventional topics and activities. It is conventional because the subject is not yet conveys the green concept, which is sounding in 2010 when the President of RI that he proclaimed 'Indonesia Go Green'. The adjustment has not been made explicitly in the curriculum, i.e. by conducting the new label of Green Entrepreneurship or Green Entrepreneurial Behavior Meanwhile, Green Entrepreneurial Behavior believed as potential support subject to form Indonesia's qualified entrepreneurs.

The implicitly concept of green learning subject finely insert in delivering course of Entrepreneurship, put up the expectation that in will internalize to the audiences, the students. Reliable entrepreneurs is one of the result from the Faculty of Business and Economy's mission in performing quality higher education service, beside providing national competitiveness by integrity scholars and masters in Economics, Management, and Accountancy. It meant to fulfill the labor market requirement in business and public sectors as well. Hence, to achieve the mission, the faculty administered to provide the compulsory subject in its three majors courses of Economics and Development Studies, Management, and Accountancy since the implementation of 2003 curriculum, and administering Entrepreneurship and Strategic Management as specific field of study for their final scholar theses in 2009. The course of Entrepreneurship delivered in the $3^{\text {rd }}$ semester and specific choice field of study in available in the $5^{\text {th }}$ semester. In $3^{\text {rd }}$ semester, the course delivering 
considered as initial debriefing for basic entrepreneurial activities in conventional lecturing activities - speech method, module for assignment, and practicing. Meantime, in the $5^{\text {th }}$ semester, they are debriefing with gaining knowledge about the process of strategic management in both SMEs and global level in the future days. Reinforcement material delivered in $6^{\text {th }}$ semester under required course of interest for Planning and Business Simulation which debriefed them with knowledge of operations/ logistic, marketing, financial, and human resources. The greatest hope for entrepreneur-ready graduation is its ability to suppress the unemployment level in Indonesia. The spirit of entrepreneurship required to be well maintaining, because green entrepreneurial behavior is an intentional behavior.

It requires initiative, pro-activity, consistency, and committed to the green way of business attitude. Under such consideration, appropriate entrepreneurship education will have much influence to scholar's attitudinal pattern and behavior in the future. Strived-demand emerged from the environmental quality, live and human welfare degradation to be green in economy practices. Intended to form green entrepreneurs, the series of research first stated by identifies whether the expectation from the finely inserting of the green entrepreneurial behavior principles into the lecturing activities in subject course of green entrepreneurial behavior, is meet the expectation of being internalized. In finding the real phenomenon of the comprehension level of student's green entrepreneurial behavior, test of instrument being administered to students in the $5^{\text {th }}$ semester whom undergo the specific field of study: Entrepreneurship and Strategic Management.

\section{Literature Review}

\subsection{Entrepreneurial Context}

Entrepreneurship being describe by Ahmad and Hoffman (2007:4) which affirms that those are persons or business owners, who seek to generate value, through the creation or expansion of economic activity, by identifying and exploiting new products, processes or markets. Entrepreneurial activity is the enterprising human action in pursuit of the generation of value, through the creation or expansion of economic activity, by identifying and exploiting new products, processes or markets. And finally, Entrepreneurship is the phenomenon associated with entrepreneurial activity. We accept that entrepreneurship as explainable phenomena - represent a certain related characteristics within its manifestation in creating value through the identification and exploitation agenda. Not every business, even the new one, is entrepreneurial. It requires further interpretation.

\subsection{Green Entrepreneurship And Entrepreneurial Behavior}

As Ahmad and Hoffman (2007:4) affirmed about entrepreneurial activity, entrepreneurship taking place in the today economy is struggling to be green in their activities and processes - namely Green Economy. There are growing necessary to be green entrepreneurs to improve and maintain natural environment while keep the business ongoing in prosperity. According to Pachaly (2012:8), green entrepreneurship define as the activities concerns individuals and organizations engaged in entrepreneurial activities that create environmental benefits by offering green final products or services. For this clarity purposes, visualized definition as follows.

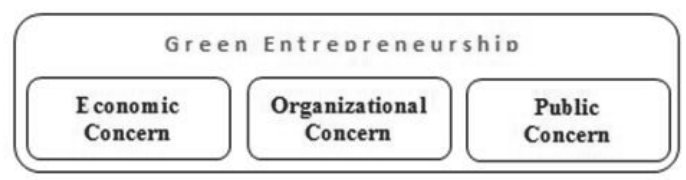

Figure 1. Area Concern of Green Entrepreneurship

Source: Adapted from Pachaly (2012)

Further explanation spell out that as a process of entrepreneurial activities, it recognizing, evaluating, and exploiting opportunities but does not have to include new venture creation since opportunities are abandon-able after evaluation, comprises nascent green entrepreneurial activity also. Green entrepreneurs intend to offer green products and services, represents their concern to contribute in reducing environmental degradation by performing suitable process for sustainable economy. This type of entrepreneurship make up of any individual's green initiative, which their 
entrepreneurial activity intends to create environmental benefits but also concern for economic returns as well.

Green behavior is behavior that minimizes harm to the environment as much as possible, or even benefits it as Steg \& Vlek (2009) cited in Science for Environment Policy (2012:2). It has been simply described as doing things well and avoiding bad. The next citation from Chatterton (2011) proposing four dimensions of behavior change, they are: The actors of the relevant behavior - this range from self-determined individuals to communities or populations; The scopes these range from isolated behaviors, such as car-free days, to lifestyles, such as complete self-suffiency; The durability this range from one-of behaviors, such as loft insulation, to enduring behaviors, such as routinely switching of lights; and the last one is The domains of relevant behavior - this refers to the target for change and ranges from the psychological (the way people think or make decisions) to the infrastructural (energy, transport and economic systems). It also refers to the scale at which the change occurs in terms of social, national, or global levels (p.5).

Entrepreneurial behavior is an intentional behavior as well as green entrepreneurial behavior - internally driven behavior. They are people who actively take initiatives to improve their current circumstances or creating new one, as stated by Robin and Judge (2013:142), namely proactive personality. They challenge status quo as challenging conventional business to be green. Myers and Smith (2007:2) identify five principles to guide proactive behavior, they are: unobtrusive (not interfering with the user's own activities or attention, without warrant), valuable (pertinent to advance the user's interests); capable (within the scope of the agent's abilities), safe (without negative consequences), user control (exposed to the scrutiny and according to the mandate of the use). User refers to the other party who enjoy benefit from the proactive behavior provides by the proactive personnel. Timmon's et al as cited in Textbook Equity (2011) identify 14 entrepreneurial characteristics as individual behavior and a process, and also possessing organizational outcome that concern to public, organization, and economy. They are: 1) drive and energy; 2) self-confidence; 3) high initiative and personal responsibility; 4) internal locus of control; 5) tolerance of ambiguity; 6) low fear of failure; 7) moderate risk taking; 8) long-term involvement; 9) Money As A Measure Not Merely An End; 10) Use of Feedback; 11) Continuous Pragmatic Problem Solving; 12) Use of Resources; 13) Self-Imposed Standards; and 14) Clear Goal Setting. Under certain characteristics, green entrepreneurial behavior stands for a form of behavior represents entrepreneurial values which fulfill the basic principles of proactive behaviors, and paying enough attention to legal aspects and its ambiguity.

Table 1. Operational Definition for Entrepreneurial Characteristic

\begin{tabular}{|c|c|}
\hline $\begin{array}{l}\text { Operating Entrepreneurial } \\
\text { Characteristics }\end{array}$ & Official Statement. For Entrepreneurial Behavior \\
\hline Green Drive and Energy & $\begin{array}{l}\text { Refers to the constellation of traits and entrepreneurial motives that represents high level of effort } \\
\text { within green consideration }\end{array}$ \\
\hline Green Self-Confidence & $\begin{array}{l}\text { Refers to high level of self esteem equipped with self-awareness and the strong believe that the } \\
\text { entrepreneurial activity to proceed its entrepreneurial activities within green consideration }\end{array}$ \\
\hline $\begin{array}{l}\text { Green Initiative and Personal } \\
\text { Responsibility }\end{array}$ & Proactively initiate to be green entrepreneurs by performing green business practice. \\
\hline Green Internal Locus of Control & $\begin{array}{l}\text { Refers to positive individual perception behavior that every faced situation is consciously green } \\
\text { based. }\end{array}$ \\
\hline Green Tolerance of Ambiguity & Refers to optimism to display green entrepreneurial behavior in its activities. \\
\hline Low Fear of Failure & Refers to the courage in dealing with failure to be green entrepreneur. \\
\hline Green Moderate Risk Taking & Refers to the attempt to minimize entrepreneurial risk by avoiding activities that summon new risk. \\
\hline Green Long-Term Involvement & $\begin{array}{l}\text { Refers to the future-oriented entrepreneurial activities that is also preserve environment - } \\
\text { organization and people comprehensively. }\end{array}$ \\
\hline $\begin{array}{l}\text { Money As A Measure Not } \\
\text { Merely an End }\end{array}$ & $\begin{array}{l}\text { Refers to the green-oriented entrepreneurial practice, uphold ideals more than just profit-oriented } \\
\text { activities, that financial aspect stands for measurement tools for its effectiveness and efficiency. }\end{array}$ \\
\hline Green Use of Feedback & Refers to prudent utilization of feedback for green-oriented entrepreneurial activities. \\
\hline $\begin{array}{l}\text { Green Continuous Pragmatic } \\
\text { Problem Solving }\end{array}$ & $\begin{array}{l}\text { Refers to effectively practicing practical problem solving and efficient in performing green - } \\
\text { entrepreneurial activities }\end{array}$ \\
\hline Green Use of Resources & $\begin{array}{l}\text { Refers to the responsible utilization of resources that are preserving environment the most while } \\
\text { beneficially for public and organization as well. }\end{array}$ \\
\hline Green Self-Imposed Standards & $\begin{array}{l}\text { Refers to the appropriate behavior in entrepreneurial practice that is not beyond its capability for } \\
\text { responsible business maintenance purpose. }\end{array}$ \\
\hline Green Clear Goa & $\begin{array}{l}\text { Refers to the clarity in establishing objectives to achieve in the future that is concern to green } \\
\text { entrepreneurial activities. }\end{array}$ \\
\hline
\end{tabular}

Source: arranged for research purposes (2012) 
Contextual definition for entrepreneurial characteristics within the green economy for green entrepreneurial behavior manifestation, has unlimited application, as long as users enjoys and recognizes the proactive behavior principles for green entrepreneurial behavior.

\subsection{Higher Education Learning}

Higher education learning process is the part of lecturer's professional responsibility. The general measurement for the effective process expressed with by student GPA. But, there is more, the learning process urgency for both party - the lecturers and the students - which contribute to the increased and developed academic skill, knowledge, and expertise. Effective lecturing activities somehow depends on its technique in teaching strategy, as Balaraman et.al (1996) conveys: (1) Practical Examples: Connecting Theory with Applications, (2) Show And Tell: Reversing Student Roles, (3) Case Studies: Bringing "Real-Life" Scenarios into the Classroom, (4) Guided Design Projects: Introducing Practical Design Experience in Classrooms, (5) Open-Ended Labs: Making Students Think Deeper, (6) The Flowchart Technique: Organizing the Flow of Thought, (7) Open-Ended Quizzes: Moving Students Away From Memorization, (8) Brainstorming: Encouraging Creativity, (9) Question-And-Answer Method: Encouraging Student Participation, (10) Software: Increasing Teaching Efficiency. It is all requires quality "plan, do, act, and review" monitoring cycle consistently.

\subsection{Previous Study}

Entrepreneurial behavior researches are being empowered to introduce further research to gain deeper understanding of green entrepreneurial behavior. Literature study by Priyono and Muqorobin (2012) about entrepreneurial behavior describes the necessity and potential development of entrepreneurship agenda since the increasing number of workforce supplied by higher education graduates that contributes to the increasing number of unemployment. There is gap between the ideals in administer the Compulsory course of Entrepreneurship with its result, within successful agenda to provide new entrepreneurs to the society. Questioning its role to cultivate entrepreneurial ethos in delivering new entrepreneurs, it is necessary to employ suitable method of learning and teaching to ease the gap, suggested model is constructive learning model for its learning activities.

Meanwhile, back in previous year, Ondracek et al (2011) traces theoretical developments of entrepreneurship from the lens of culture and the role that culture has played by entrepreneurship's education. Entrepreneurship education at university level is a recent phenomenon, since its study emphasizes in the history. Moreover, entrepreneurship education lacks theory and an accepted paradigm, as cited from Vesper, 1982; Fiet, 2000a and 2000b; Bechard and Gregoire, 2005; and Kuraktko, 2005. US have settled in two consistent educational approaches, they are: entrepreneurship for wealth-creation focused courses and small business as form-creation focused courses; with considerable standardization for each approach. As Fayolle (2008), citing Kirby (2007) in Ondracek et al (2011), he divides the objectives of entrepreneurship education into categories, as: Teaching students about the role and function of entrepreneurs; "developing in their students the attributes of the successful entrepreneur;" "education for enterprise; "education through enterprise-with using the new venture creation process to help students acquire a range of both business understanding and transferable skills or competences;" education "in an entrepreneurial environment".

\section{Research Method and Design}

Stands for the preliminary study, preparing the reliable instrument for green entrepreneurial behavior study at higher education become its main purposes. Regarding to common purposes of social scientific study, which is to test its research hypothesis generated from theory (Ghozali, 2006), this study is aim to seek for answer the description research question. Proposed research question is: How many of the students (in percentage) who choose the specific field of study: Strategic Management and Entrepreneurship comprehends the green entrepreneurial behavior principles? In order to answer the question, proposes assumption in formal research as hypothesis $\left(\mathrm{H}_{0}\right.$ and $\left.\mathrm{H}_{2}\right)$ statements are:

$\mathrm{H}_{0}=$ More than $50 \%$ of the student who choose the specific field of study Strategic Management and Entrepreneurship do not comprehend the principles of green entrepreneurial behavior,

$\mathrm{H}_{\mathrm{a}}=$ More than $50 \%$ of the student who chose the specific field of study Strategic Management and Entrepreneurship comprehends the principles of green entrepreneurial behavior.

Series of test in generating instrument for depict the student's level of green entrepreneurial behavior comprehensions are: descriptive statistic of frequencies, test of tem validity and instrument reliability. The chosen level of significant is at $5 \%$ for saturated sample that include the entire class member as research respondents. 


\section{Result and Analysis}

\subsection{Individual General Characteristics}

The first statistical analysis is the descriptive statistic to provide us with general information of respondent's characteristic. Summarized respondent's characteristic tabulated as follow.

Table 2. Summary of Respondent's Individual General Characteristics

\begin{tabular}{|c|c|c|c|c|c|c|c|}
\hline Sex & & \multicolumn{2}{|c|}{ Age [y.o] } & \multicolumn{2}{|c|}{ GPA } & \multicolumn{2}{|c|}{ Parent's profession } \\
\hline $\mathrm{F}$ & $46.7 \%$ & 20 & $80 \%$ & $2.70-2.99$ & $26.7 \%$ & Self-employee & $26.7 \%$ \\
\hline $\mathrm{M}$ & $53.5 \%$ & $\begin{array}{l}21 \\
33:\end{array}$ & $\begin{array}{c}13.3 \% \\
6.7 \%\end{array}$ & $3.00-3.70$ & $93.3 \%$ & Non self-employee & $93.3 \%$ \\
\hline
\end{tabular}

Sources: processed data, 2014.

The above summary conveys that both genders are relatively provided with the same opportunity to choose their field of study equally. In the $5^{\text {th }}$ semester, students in age of 20 years old are dominant. They were born in \pm 1994 , nearly the era of economy crisis since the downturn of IDR exchange rate to US\$. They have spent they childhood in that era and their family are proven to be survive. But as we see, that dominant survivors are non self-employee parents. This condition may leads to student's perception that being employee is the best choice of profession and entrepreneurial intention. Especially for those with the high GPA, since most of job offered require a high GPA. If this thought is believed by the most of student or even society, it will be harder to lever the number of entrepreneurs in Indonesia, at least to reach the minimum requirement of $2 \%$ from its population.

\subsection{Descriptive Statistic for Questionnaire's Items}

To gain deeper understandings for student's comprehension about green entrepreneurial behavior principles, student's respond are summarizes in Table 3 . The responds, represent by Likert's 5 scale for reveals their individual perception in score of: 5 if fully understand; 4 if understand; 3 if neutral; 2 if do not understand; and 1 if do not understand at all. Description of student's green entrepreneurial behavior comprehension displays in below table.

Further explanation for research green entrepreneurial behavior indicators described for in tha instrument items, resulted in a mean average score of 3.485 (accepted as neutral), namely: the middle category. Providing instrument with the middle category is aimed to facilitate the moderate trait standing respondents, in order to avoid them to feel being forced to be bipolar. When respondents chose to moderate, there are many other influence factors. As Shaw and Wright cited by Widhiarso (2010), there are three possibilities of influence factors, they are: 1) they do not have an attitude or opinion about it, (2) they want to provide a balanced assessment, or (3) they have not provided stance or a clear opinion. Therefore, the total average score of 3.485 implies those certain condition or that they do not understand the item and feel uncomfortable with a given statement. This condition is considered as a reasonable condition in this situation because the principle green entrepreneurial behavior only implicitly conveyed in lecturing. It only implied and tuck in the course of material as a form of concern for the quality of life's degradation. The existence the middle category, the measurement reliability and item validity did not experience differences, but only on the variant scores. The middle category within, typically resulted with higher data variation. But as we see in above Table, all the status of variance is consider as small, since they are no more than $20 \%$ of it mean score. 
Table 3. Descriptive Statistics for GEB Questionnaire items

\begin{tabular}{|c|c|c|c|c|c|c|c|c|c|}
\hline \multirow[b]{2}{*}{ Indicators } & \multicolumn{6}{|c|}{ Descriptive Statistics } & \multicolumn{3}{|c|}{ Variability } \\
\hline & Code & $\mathbf{N}$ & Min. & Max. & Mean & Deviation Std. & $\begin{array}{c}20 \% \\
\text { DS }\end{array}$ & compared to Mean & variance \\
\hline \multirow{4}{*}{ Green Drive and Energy } & DE1 & 15 & 2 & 5 & 3.87 & .915 & 0.18 & $<$ & small \\
\hline & DE2 & 15 & 2 & 5 & 3.67 & .724 & 0.14 & $<$ & small \\
\hline & DE3 & 15 & 1 & 5 & 3.87 & 1.060 & 0.21 & $<$ & small \\
\hline & DE4 & 15 & 2 & 5 & 3.93 & .799 & 0.16 & $<$ & small \\
\hline \multirow{3}{*}{ Green Self-Confidence } & SC5 & 15 & 2 & 5 & 3.87 & .834 & 0.17 & $<$ & small \\
\hline & SC6 & 15 & 2 & 5 & 3.87 & .640 & 0.13 & $<$ & small \\
\hline & HP7 & 15 & 1 & 5 & 4.00 & 1.195 & 0.24 & $<$ & small \\
\hline \multirow{3}{*}{ Green Initiative and Personal Responsibility } & HP8 & 15 & 1 & 5 & 3.80 & 1.014 & 0.20 & $<$ & small \\
\hline & HP9 & 15 & 2 & 5 & 3.80 & 1.082 & 0.22 & $<$ & small \\
\hline & HP10 & 15 & 2 & 5 & 3.87 & .915 & 0.18 & $<$ & small \\
\hline \multirow{2}{*}{ Green Internal Locus of Control } & ILC11 & 15 & 2 & 5 & 3.73 & .884 & 0.18 & $<$ & small \\
\hline & ILC12 & 14 & 2 & 5 & 3.57 & 1.016 & 0.20 & $<$ & small \\
\hline \multirow{2}{*}{ Green Tolerance of Ambiguity } & TA13 & 14 & 1 & 4 & 2.64 & .842 & 0.17 & $<$ & small \\
\hline & TA14 & 14 & 1 & 4 & 2.57 & .938 & 0.19 & $<$ & small \\
\hline \multirow{2}{*}{ Low Fear of Failure } & LF15 & 15 & 1 & 5 & 3.27 & 1.223 & 0.24 & $<$ & small \\
\hline & LF16 & 15 & 1 & 5 & 3.20 & 1.082 & 0.22 & $<$ & small \\
\hline \multirow{2}{*}{ Green Moderate Risk Taking } & MRT17 & 14 & 2 & 5 & 3.71 & .994 & 0.20 & $<$ & small \\
\hline & MRT18 & 14 & 2 & 5 & 3.29 & 1.069 & 0.21 & $<$ & small \\
\hline \multirow{2}{*}{ Green Long-Term Involvement } & LTI19 & 15 & 2 & 5 & 3.73 & .961 & 0.19 & $<$ & small \\
\hline & LTI20 & 15 & 2 & 5 & 3.60 & 1.056 & 0.21 & $<$ & small \\
\hline \multirow{2}{*}{ Money As A Measure Not Merely an End } & MM21 & 15 & 2 & 5 & 4.13 & .990 & 0.20 & $<$ & small \\
\hline & MM22 & 15 & 2 & 5 & 4.00 & 1.000 & 0.20 & $<$ & small \\
\hline \multirow{2}{*}{ Green Use of Feedback } & UF23 & 15 & 1 & 5 & 3.00 & 1.069 & 0.21 & $<$ & small \\
\hline & UF24 & 15 & 1 & 5 & 3.00 & 1.069 & 0.21 & $<$ & small \\
\hline \multirow{2}{*}{ Green Continuous Pragmatic Problem Solving } & CP25 & 15 & 1 & 4 & 2.80 & .941 & 0.19 & $<$ & small \\
\hline & CP26 & 15 & 1 & 4 & 2.60 & .828 & 0.17 & $<$ & small \\
\hline \multirow{2}{*}{ Green Use of Resources } & LFF27 & 15 & 1 & 5 & 3.40 & 1.121 & 0.22 & $<$ & small \\
\hline & LFF28 & 15 & 1 & 5 & 3.27 & 1.100 & 0.22 & $<$ & small \\
\hline \multirow{2}{*}{ Green Self-Imposed Standards } & SS29 & 14 & 2 & 5 & 3.07 & 1.072 & 0.21 & $<$ & small \\
\hline & SS30 & 14 & 2 & 5 & 2.93 & 1.141 & 0.23 & $<$ & small \\
\hline \multirow{2}{*}{ Green Clear Goal Setting. } & CGS31 & 13 & 1 & 5 & 3.77 & .927 & 0.19 & $<$ & small \\
\hline & CGS32 & 13 & 2 & 4 & 3.69 & .630 & 0.13 & $<$ & small \\
\hline \multicolumn{2}{|l|}{ Valid N (list wise) } & 12 & al & $\mathrm{Scc}$ & .485 & & & & \\
\hline
\end{tabular}

Source: processed data, 2014

\subsection{Test of Item's Validity and Instrument's Reliability}

Criteria for item's validity under assigned significant level of $5 \%$ with rtable for degree of freedom of $32-2=30$ is 0,2327 . The item is considered valid if Corrected Item-Total Correlation score resulted in positive and higher than the rtable Score of 0,2327 . Under such circumstances, the each round of test result as follow.

Table 4. Test of Item's Validity Rounds

\begin{tabular}{|c|c|c|c|c|c|c|}
\hline \multicolumn{6}{|c|}{ Item-Total Statistics } & \multirow[b]{2}{*}{$\begin{array}{l}\text { Result for acquired } r \text { - } \\
\text { table } 0,2327\end{array}$} \\
\hline $\begin{array}{c}\text { Round } \\
\text { Test }\end{array}$ & Code & $\begin{array}{c}\text { Scale Mean if Item } \\
\text { Deleted }\end{array}$ & $\begin{array}{l}\text { Scale Variance if } \\
\text { Item Deleted }\end{array}$ & $\begin{array}{c}\text { Corrected Item-Total } \\
\text { Correlation }\end{array}$ & $\begin{array}{l}\text { Cronbach Alpha if } \\
\text { Item Deleted }\end{array}$ & \\
\hline 1 & CP26 & 108.67 & 354.242 & -.187 & .944 & Not valid \\
\hline 2 & CP25 & 105.75 & 360.023 & -.179 & .950 & Not Valid \\
\hline
\end{tabular}

Source: Processed data, 2014. 
The first two rounds exclude 2 items from indicator of: Green Continuous Pragmatic Problem Solving since both resulted score are negative at their Corrected Item-Total Correlation. This finding considered as reasonable since respondent are all student are not professionals, therefore not yet face any form of entrepreneurial problem for them to solve practically and to efficiently performing green entrepreneurial activities. They are just an undergraduate student. The final round generates valid items being displayed in Table 5, as the final result for instrument's reliability Cronbach Alpha is 0.950 with the $\mathrm{N}$ of item 30 - as valid questionnaire items, after removing 2 items of Green Continuous Pragmatic Problem Solving indicators. Reliable questionnaire is being held until further intellectual rights processed.

Table 5. Test of Item's Validity Rounds 3

\begin{tabular}{|c|c|c|c|c|c|}
\hline \multicolumn{5}{|c|}{ Item-Total Statistics } & \multirow[b]{2}{*}{$\begin{array}{l}\text { Result for acquired } r \text { - } \\
\text { table } 0,2327\end{array}$} \\
\hline & $\begin{array}{c}\text { Scale Mean if Item } \\
\text { Deleted }\end{array}$ & $\begin{array}{c}\text { Scale Variance if Item } \\
\text { Deleted }\end{array}$ & $\begin{array}{c}\text { Corrected Item-Total } \\
\text { Correlation }\end{array}$ & $\begin{array}{c}\text { Cronbach Alpha if Item } \\
\text { Deleted }\end{array}$ & \\
\hline DE1 & 101.75 & 335.659 & .756 & .947 & Valid \\
\hline DE2 & 102.08 & 343.902 & .537 & .949 & Valid \\
\hline DE3 & 101.75 & 332.023 & .707 & .947 & Valid \\
\hline DE4 & 101.75 & 337.114 & .708 & .947 & Valid \\
\hline SC5 & 101.75 & 338.568 & .769 & .947 & Valid \\
\hline SC6 & 101.83 & 343.788 & .637 & .948 & Valid \\
\hline HP7 & 101.67 & 320.970 & .903 & .945 & Valid \\
\hline HP8 & 102.00 & 331.273 & .719 & .947 & Valid \\
\hline HP9 & 101.92 & 331.356 & .736 & .947 & Valid \\
\hline HP10 & 102.00 & 331.636 & .781 & .947 & Valid \\
\hline ILC11 & 102.00 & 331.091 & .797 & .946 & Valid \\
\hline ILC12 & 102.17 & 329.606 & .743 & .947 & Valid \\
\hline TA13 & 103.08 & 349.720 & .287 & .951 & Valid \\
\hline TA14 & 103.25 & 347.477 & .348 & .950 & Valid \\
\hline LF15 & 102.50 & 328.273 & .645 & .948 & Valid \\
\hline LF16 & 102.67 & 334.061 & .578 & .948 & Valid \\
\hline MRT17 & 102.00 & 332.909 & .834 & .946 & Valid \\
\hline MRT18 & 102.58 & 330.265 & .704 & .947 & Valid \\
\hline LTI19 & 101.92 & 339.174 & .578 & .948 & Valid \\
\hline LTI20 & 102.17 & 340.152 & .514 & .949 & Valid \\
\hline MM21 & 101.42 & 334.811 & .752 & .947 & Valid \\
\hline MM22 & 101.58 & 336.629 & .655 & .948 & Valid \\
\hline UF23 & 102.92 & 338.629 & .491 & .949 & Valid \\
\hline UF24 & 102.92 & 338.629 & .491 & .949 & Valid \\
\hline LFF27 & 102.42 & 343.174 & .336 & .951 & Valid \\
\hline LFF28 & 102.58 & 340.811 & .404 & .950 & Valid \\
\hline SS29 & 102.92 & 349.902 & .264 & .951 & Valid \\
\hline SS30 & 103.08 & 345.174 & .379 & .950 & Valid \\
\hline CGS31 & 102.00 & 333.636 & .722 & .947 & Valid \\
\hline CGS32 & 102.08 & 339.720 & .828 & .947 & Valid \\
\hline
\end{tabular}

Source: Processed data, 2014.

\subsection{Answering Research's Question}

Proposed research question "how many of the students (in percentage) who choose the specific field of study: Strategic Management and Entrepreneurship comprehends the green entrepreneurial behavior principles?" is checked for its conformity provided average respond by students, approaches by descriptive statistic of frequency. 
Table 6. Respondent's Statistics of reliable questionnaire

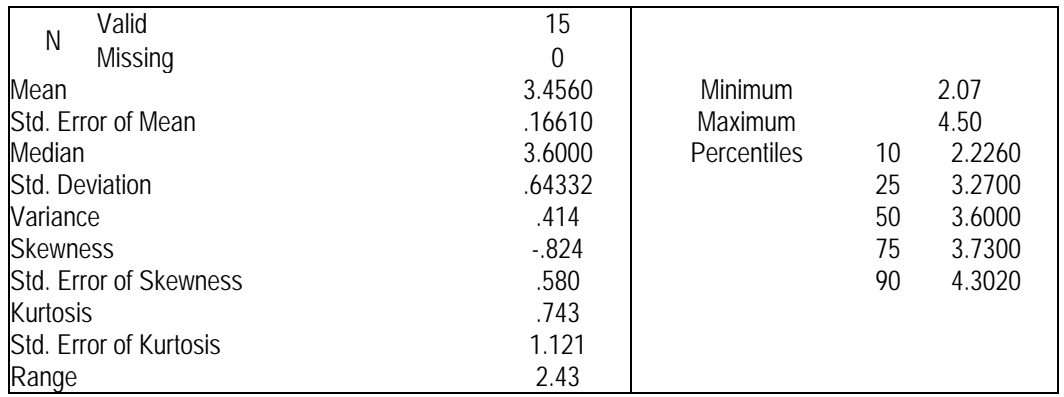

Source: Processed data, 2014

$\mathrm{N}$ valid of 15 and 0 (null) missing states that the entire data is ready to be processed. Mean score resulted in 3.4560 with Std. Error of Mean 0.16610 means that the average score of student's comprehension of green entrepreneurial behavior principles lies between 3 standard deviation it is $3.4560 \pm(3 \times 0.16610)$ resulted in average of 2.9577 to 3.9543 . Scale of 2 represents the statement that they do not understand the green entrepreneurial behavior principles. And the scale of 3 represents the moderate standing respondents that they do not understand the item and feel uncomfortable with a given statement. It is if the averages students are have no idea about the green entrepreneurial behavior principles. The median score resulted in 3.6000 showing that $50 \%$ student's score of their green entrepreneurial behavior principles comprehension is less than 3.4560 and the other $50 \%$ is more than 3.4560 . Standard deviation resulted in $0.64332-$ the square score of standard deviation of 0.414 - represents the range of student's comprehension of green entrepreneurial behavior principles lies between 3 standard of deviation, it is: $3.4560 \pm(3 \times 0.64332)$ resulted in range 2.81268 until 4.09932. Above explanation about the scale 2, then the scale of 4 represents the contrary statement that they comprehend the green entrepreneurial behavior principles.

The size of skewness is $(-0.824)$ provide the skewness ratio (skewness score: standard error skewness) is $=(-$ 0.824 ) / $0.580=-1.4206897$. Meanwhile, the size of kurtosis is 0.743 with kurtosis ration (size of kurtosis: kurtosis error standard) is $=0.743 / 1.121=0.6628011$. Assumption for normal data distribution is if the ration of ratio kurtosis and skewness within range $(-2)$ until (+2). Therefore with kurtosis ratio of $(-1.4206897)$ and skewness ratio of $(+0.6628011)$ are within range, assumes that data is normally distributed. The minimum respond scale is 2.07 and the maximum respond scale is 4.50 represent that even though there are students without comprehension of green entrepreneurial behavior, there are also students who comprehend the green entrepreneurial behavior principles. This finding is out of the range standard deviation 2.81268 until 4.09932 (the 2.07 and 4.5), reflecting wide deviation students comprehension with data maximum to minimum data range of $4.40-2.07=1.8$. Exposed percentiles somehow answer the research question by its interpretation as below.

Table 7. Interpreting Percentiles

\begin{tabular}{|l|l|l|}
\hline Percentiles & Interpretations \\
\hline 10 & 2.2260 & $10 \%$ of Student's green entrepreneurial behavior comprehension average score is below 2.2260 \\
\hline 25 & 3.2700 & $25 \%$ of Student's green entrepreneurial behavior comprehension average score is below 3.2700 \\
\hline 50 & 3.6000 & $50 \%$ of Student's green entrepreneurial behavior comprehension average score is below 3.6000 \\
\hline 75 & 3.7300 & $75 \%$ of Student's green entrepreneurial behavior comprehension average score is below 3.7300 \\
\hline 90 & 4.3020 & $90 \%$ of Student's green entrepreneurial behavior comprehension average score is below 4.3020 \\
\hline
\end{tabular}

Source: processed data, 2014.

Answering proposed research question about how many of the students (in percentage) who choose the specific field of study: Strategic Management and Entrepreneurship comprehends the green entrepreneurial behavior principles by resulted percentile. Scale 4 represents student's perceived comprehension of green entrepreneurial behavior principles. If $90 \%$ of Student's green entrepreneurial behavior comprehension average score is below 4.3020 will make the rest are 
Students who comprehend the green entrepreneurial behavior principles: $10 \%$. Temporary answer expressed in $\mathrm{H}_{0}$ (More than $50 \%$ of the student who choose the specific field of study Strategic Management and Entrepreneurship do not comprehend the principles of green entrepreneurial behavior) is accepted, since there are only $10 \%$ of the students ( $15 \mathrm{x}$ $10 \%=1.5$ ) or 2 student perceive themselves understand it. This answer is temporary until further study for its significance.

\section{Conslusion}

Research analysis answers that there are only $10 \%$ of the student who choose the specific field of study Strategic Management and Entrepreneurship perceived they understand the green entrepreneurial behavior principles. The rest of $90 \%$ are not. It means, among 15 students, only 2 of them perceived they understand the green entrepreneurial behavior principles, the rest of 13 are not. Therefore, to increase the amount of student comprehension to green entrepreneurial behavior principles, this research proposes three practical suggestions. They are:

1. Providing the subject of green entrepreneurial behavior inclusively in lecturing material formally/ explicitly, or deliver it as specific part/ chapter of learning material.

2. Preparing the faculty with relevant competence to deliver the course of material: green entrepreneurial behavior

3. Updating the content of the curriculum more than just the system of administration only.

\section{References}

Ahmad, Nadim dan Hoffman, Anders (2007). A framework for Addressing and Measuring Entrepreneurship. Organization for Economic Co-operation and Development/ OECD. Entrepreneurship Indicators Steering Group. Available from https://www1.oecd.org/std/ business-stats/39629644.pdf

Balaraman, Pabhu., Khan, Muneer., Fleming, Mark., Nowicki, David., dan Lacey, Joe (1996). Strategies for Effective Teaching: A Handbook for Teaching Assistants. Courter, Sandra ., Balaraman, Prabhu, Lacey, Joe., dan Hochgraf, Clark. [Editor]. Office of Asociate Dean of Academic Affairs, College of Engieneering. Madison: University of Wisconsin. Available at http://www.teknologi pendidikan.net/wp-content/uploads/2009/02/strategies.pdf

Ghozali, Imam. (2006). Statistik Non-Parametrik: Teori \& Aplikasi dengan Program SPSS. Badan Penerbit Universitas Diponegoro. Semarang.

Hadi Suprapto dan R. jihad Akbar (2013, 8 Juni). Menkop: Jumlah Wirausahawan RI Kalah Jauh. Tersedia pada Situs Berita Online Nasional Viva News.com. Available at: bisnis.news.viva.co.id/print_detail/printing/322681-menkop_-jumlah-wirausahawan-rikalah-jauh

Myers, Karen and Smith, Neil Yorke. (n.d.). Proactive Behavior of a Personal Assistive Agent. Unpublished scientific article. SRI International: Artificial Intelligence Center. Menlo Park, USA

Ondracek, James., Berstsch, Andy., and Saeed, M. (2011). Entrepreneurship Education: Culture's Rise, Fall, and Unresolved Role. Interdisciplinary Journal of Contemporary Research in Business. Vol. 3, No. 5. P.15-28.

Pachally, Mahalia Von Wallenberg. 2012. Barriers and Triggers to Green Entrepreneurship: An Exploratory Study. Unpublished Doctoral Dissertation. Erasmus School of Economics. Rotterdam, Netherland.

Priyono, Edi., dan Muqorobin, Agus. (2012). Studi Literatur Terkait Perilaku Kewirausahaan. Research article. Available at http:/leprints. unisbank.ac.id/454/1/ARTIKEL-53.pdf

Robbins, Stephen P. (2013). Organizational Behavior. Pearson Education. Prentice hall.

Science for Environment Policy. (2012). Future Brief: Green Behavior. Scientific article. October. Issue 4. Available at: http://ec.europa. eu/environment/integration/research/newsalert/pdf/FB4.pdf

Text Book Equity. 2011. Entrepreneurial Behavior: Transforming an Innovative Idea into an Entrepreneurial Product. Adopted Open Textbook. ISBN-13: 978-1463550417. ISBN-10: 1463550413.

Widhiarso. (2010). Pengembangan Skala Psikologi: Lima Kategori Respons ataukah Empat Kategori Respons? Psychology Faculty of Gadjah Mada Unversity. Available at: http://widhiarso.staff.ugm.ac.id/files/widhiarso_2010___respon_alternatif_tengah_pada_ skala_likert.pdf 